\title{
Hypervascularisation of colonic graft for oesophageal replacement: literature review and own experience
}

\section{Hiperwaskularyzacja przeszczepu okrężnicy w celu odtworzenia przełyku - przegląd piśmiennictwa i doświadczenia własne}

\author{
Aliaksandr Varabei ${ }^{1}$, Yezhy Vizhynis ${ }^{1}$, Anvar Makhmudov ${ }^{1}$, Dzmitry Chepik², Yury Arlouski ${ }^{1}$, Margarita Gulevich² \\ ${ }^{1}$ Surgery Department, Belarusian Medical Academy of Postgraduate Education, Belarus \\ Head of the Academy: Prof. Aliaksandr Varabei \\ ${ }^{2}$ Surgery Department, Minsk Regional Clinical Hospital, Minsk, Belarus \\ Head of the Department: Dzmitry Chepik MD
}

Key words: oesophagoplasty, colonic graft, hypervascularisation.

Słowa kluczowe: ezofagoplastyka, przeszczep okrężnicy, hiperwaskularyzacja.

\begin{abstract}
Colonic interposition in post-burn oesophageal strictures still remains a challenge. The main issue is the viability of the cervical portion of the colonic graft. The article provides a literature review on mesentericography and hypervascularisation of colonic graft for oesophageal replacement. The authors share their own experience. The study of the colic arterial anatomy enables one to choose its more perfused portion for oesophageal replacement. In insufficient blood supply, direct anastomoses with cervical or internal thoracic vessels have been proposed for hypervascularisation of the cervical part of graft. The technique of vessel ligation with a subsequent intensive collateral blood flow has been designed for hypervascularisation of the colonic graft.
\end{abstract}

\section{Streszczenie}

Wstawka z okrężnicy w zwężeniach przełyku po oparzeniach nadal stanowi wyzwanie. Głównym problemem jest żywotność szyjnej części przeszczepu okrężnicy. W artykule przedstawiono przegląd piśmiennictwa dotyczącego mezenterikografii i hiperwaskularyzacji przeszczepu okrężnicy w celu odtworzenia przełyku. Autorzy przedstawiają także doświadczenia własne. Badanie anatomii tętnic okrężniczych pozwala na ich wybór do unaczynienia części okrężnicy zastępującej przełyk. W przypadku niedostatecznego dopływu krwi zaproponowano bezpośrednie zespolenie z naczyniami szyjnymi lub naczyniami piersiowymi wewnętrznymi w celu hiperwaskularyzacji szyjnej części wszczepu. Technika podwiązania naczyń z następczą intensyfikacją krążenia obocznego może być zastosowana również do poprawy unaczynienia części okrężnicy mającej zastąpić przełyk.

\section{Introduction}

In 1911, Kelling was the first to use the transverse colon as an oesophageal substitute in a patient presenting with obturating oesophageal cancer [1]. Today, however, the surgeons are still not satisfied with the outcomes of colonic interposition in post-burn oesophageal strictures. Thomas et al. summarised the results of oesophagocoloplasty in oesophageal cancer and benign oesophageal disorders performed in 11 surgical centres all over the world between 1987 and 2007. In total, 1163 cases were reviewed. Necrosis of the cervical portion of the colonic graft amounted to $0-7.5 \%$; cervical anastomotic leaks $3.3-14.8 \%$; stenosis $2-24 \%$; and postoperative mortality made $0-16.7 \%$ [2]. According to Ahmed, Spitz and Freeman, and Cass, ischaemia or necrosis of the colonic graft occurred in $3-15 \%$ of cases [3, 4]. In 1988, De Meester published the results of colonic interposition for oesophageal replacement: left colonic graft necrosis made $4.6 \%$; right colonic graft necrosis $-10.8 \%$ [5].

Based on 600 autopsies, Sonneland et al. described 24 patterns of the colonic vascular anatomy and classified them into seven major groups. The right colic artery was absent in $12.6 \%$, and the middle colic artery in 3\% of cases. An anomalous pattern of the right colic arteries was seen in $9.4 \%$ and multiple middle colic arteries in $8.6 \%$, the classic anatomy of the right colon being found in $68 \%$ only [6].

\section{Preoperative mesentericography}

With the technique of invasive angiography developed by Seldinger in 1953, a more detailed study of surgical anatomy of colic vessels, features of collateral and intraparietal circulation, and venous out- 
flow continued [7]. In 1985, Marston published his fundamental monograph summarising his own and international experience in mesentericography [8]. In 1977, Ventemiglia et al. demonstrated that in $70 \%$ of observations there was a discontinuous marginal arcade between the middle and the right colic artery with a potential risk of ischaemia in hepatic flexure when creating the right colonic graft [9].

These data were confirmed by other authors [1012]. Kralik, Turek, and Nick proved that marginal venous anastomoses are always well-developed in the left colon, and the venous outflow from the basin of the ascending and transverse colon is insufficient in $20-30 \%$ of people $[13,14]$. These findings demonstrated the left colon to be more appropriate for oesophageal replacement.

Thomas et al. established a total absence of middle colic artery in 25\% and right colic artery in 20\%; anastomosis between ileocolic and right colic artery in 5\%; and marginal Drammond's artery in the right part of the colon in $25-75 \%$ of cases. Ileocolic artery is the most constant branch of the superior mesenteric artery [15]. Ficher and Fry proved that in almost half of the patients, the arc of Riolan is discontinuous and not functional for adequate blood circulation [16], and in $5 \%$ of patients, the arc of Riolan is totally absent $[17,18]$

In 1995, at the Surgery Clinic of Professor T. De Meester (Los Angeles, USA), five angiographic criteria for successful oesophageal replacement using the left colonic graft were described: 1 ) a patent inferior mesenteric artery; 2) a visible ascending branch of the left colic artery; 3) a well-defined anastomosis between the left branch of the middle colic artery and the ascending branch of the left colic artery; 4) a single common trunked middle colic artery dividing into right and left branches; and 5) a separate origin of the right colic artery. Sufficient blood supply to a cervical part of the left colonic graft fulfilled four or five criteria [19].

Preoperative angiography is of particular importance in patients over 60 years old due to highly probable atherosclerosis [18]. Thomas et al. (Marseille, France) consider the preoperative angiography to be indicated in lower extremities chronic arterial insufficiency, aortic aneurysm due to a highly probable stenosis or occlusion at the inferior mesenteric artery origin, history of large abdominal operations with probable ligation of colic vessels, and the need for a long colonic conduit with cervical oesophageal or pharyngeal anastomosis [2]. From 1956 to 1997, Wain et al. performed 32 preoperative mesentericographies; an anomalous pattern of blood supply was detected in $12(37.5 \%)$ cases. In benign oesophageal disorders, graft ischaemia was found in $9 \%$ of 52 colonic interpositions [20].

However, some other authors consider routine angiography not to be essential because of specific complications, high price, and discrepancy between the findings of mesentericography and intraoperative monitoring of the collateral blood supply [18, 19, 21].

The choice of oesophageal replacement method based on mesentericography allowed De Meester to decrease the rate of cervical oesophagocolonic anastomosis leakage by up to $1.5 \%$ and cervical graft necrosis by up to $2 \%$ [17]. Loinaz and Wilkins actively support the preoperative mesentericography [22, 23]. Nowadays, non-invasive computed tomography with vascular enhancement and $3 \mathrm{D}$ reconstruction is being increasingly used for preoperative diagnosis [24].

\section{Prevention of insufficient blood flow in the colonic graft}

In small intestine interposition, the most common cause of cervical graft necrosis is its ischaemia due to insufficient blood supply through the jejunal arcades. In colonic retrosternal interposition, in addition to arterial insufficiency, graft necrosis can occur due to disturbed venous circulation [2, 13, 14, 18, 19]. Before ligation and crossing, all surgeons clip the colonic graft arteries with vascular clumps - "bulldogs". Surgeons should be alarmed by possible ischaemia of future colonic graft as well as by any signs of venous hypertension [17].

De Meester suggested resecting the left sternoclavicular joint using a Gigli saw to prevent compression of a bulky mesentery [17]. Chang et al. and Orringer always perform the same procedure $[25,26]$. Thomas et al. excise the left sternoclavicular joint if four fingers together cannot be placed behind the manubrium [2].

In addition to excision of the left sternoclavicular joint, the twisting of the vascular pedicle should be avoided in order to prevent damage to mesenteric veins and venous stasis [18]. De Meester described five techniques to save an adequate blood flow to the left colonic graft: 1) to preserve the ascending branch of the left colic artery for additional supply from the sigmoid arteries and graft venous drainage through sigmoid and haemorrhoidal veins; 2) to ligate middle colic arteries before they divide into right and left branches; 3 ) to avoid tension of vascular pedicle from the pericardium - if indicated, the latter is dissected longitudinally at $2-3 \mathrm{~cm}$ and stitched cross-like according to Heineke-Mikulicz pyloroplasty; 4) to leave the marginal mesenteric vessel intact at the point of transection of the colonic graft; and 5) to perform the two-stage oesophagocoloplasty if the blood flow in the cervical portion of the graft is not sufficient [19].

To create a maximally long graft and to anastomose it with the pharynx after oesophagostomy, Lees twice successfully brought the initial portion of the ascending colon to the cervical region through the posterior mediastinum. He transected the right and middle colic arteries. The blood supply was provided from the left colic artery [27]. Furst et al. (Klinikum 
Grosshadern, Munich, Germany) suggested not to mobilise the splenic flexure of the colon for better blood supply to the graft during the operation by Lees. From January 1997 to June 1998, they performed 12 oesophagostomies and three oesophagogastrectomies using cervico-hiatal approach with oesophagocoloplasty. No graft ischaemia was noted in these cases [21].

Chang et al. and Orringer proposed to assess the arcade blood flow in the cervical portion of the future colonic graft using Doppler ultrasound intraoperatively after clipping the colic arteries with "bulldogs" $[25,26]$.

De Meester and Wain et al. put the graft into a saline-soaked plastic bag in the abdominal cavity to avoid damage of the mesenteric vessels and only then passed the colonic graft through a retrosternal tunnel $[17,20]$.

\section{Direct revascularisation of the colonic graft for oesophageal replacement}

Carrel (John Hopkins University Hospital, Baltimore, USA), for the first time in the world experimentally, successfully transplanted a portion of a dog's small intestine to the cervical region constructing microvascular anastomoses between graft vessels and the common carotid artery and internal jugular vein of the animal [28].

Carrel's experimentally grounded idea of direct revascularisation was reborn at Baltimore University. Exactly 40 years after this experiment, for the first time in the world, the Head of the Surgical Clinic at John Hopkins University Hospital in Baltimore W. Longmire Jr. introduced this idea to clinical practice. On April 15, 1946 he performed direct vascular anastomoses of the first jejunal artery and the vein of the cervical portion of the subcutaneously routed jejunal graft with similar internal thoracic vessels using binocular loupe and atraumatic threads in a 28 -year-old patient with extensive post-burn stricture of the thoracic oesophagus [29]. Longmire resected the cartilages of ribs II-III on the left to ensure access to the internal thoracic vessels. He later successfully performed four procedures with revascularisation in children with congenital oesophageal atresia complicated by tracheoesophageal fistula [30]. In 1956 Russian surgeon Androsov introduced for the first time in the world the technique of mechanical vessel suturing. It was created by Russian engineer Gudov in 1950 [31].

In 1959, to complete oesophageal replacement, Seidenberg for the first time made a free transplantation of the small intestine portion instead of cutaneous graft to the cervical region. To maintain this intestinal graft viability, he performed the direct revascularisation and then created an anastomosis between the cervical oesophagus and proximal portion of the small intestine graft. The distal end of the latter was connected with the proximal end of the jejunal graft [32].
These outstanding achievements of oesophageal surgery were not demanded for some time because in the 1950s French surgeons revealed the benefits of oesophagocoloplasty, in which direct revascularisation was rare.

In 1997, Schwabegger et al. published the results of 86 autopsies. They proved that the average diameter of the internal thoracic veins is large enough: both in men and women it is close to $1.6 \mathrm{~mm}$ on the left and $2.3 \mathrm{~mm}$ on the right. This report has revived interest in direct revascularisation of the small intestine graft for oesophageal replacement [33]. At the end of the $20^{\text {th }}$ century, microvascular and plastic surgery rapidly progressed all over the world. Up-to-date operating microscopes, suture material, and special equipment allowed microsurgeons a successful creation of arterial and venous anastomoses of small and extra-small diameters [34]. Moreover, the resection of the left sternoclavicular joint in retrosternal oesophagoplasty ensured good access to the internal thoracic vessels.

Ascioti et al. and Swisher et al. preferred the retrosternal routing of the jejunum [35, 36]. Heitmiller et al. performed sternotomy that would make the pulling more secure [37]. According to their data, in direct revascularisation of a small intestine graft on the neck, the necrosis was seen in $1.0 \%$ and the stricture of the cervical anastomosis in $4.8-18.8 \%$; no revascularisation was revealed in $8.3 \%$ and $48.6 \%$, respectively.

Some other authors did not use the thoracic vessels for the hypervascularisation of the jejunum, but the external carotid artery and internal jugular vein by Carrel [28] or transverse cervical artery and the internal carotid vein $[38,39]$ being taken. The latter vessels were preferred for the revascularisation of colonic graft too $[40,41]$.

In oesophageal cancer, Shirakawa et al. performed 41 revascularisations of 347 oesophagocoloplasties between 1998 and 2004. The construction of arterial and subsequently venous anastomosis took them $15 \mathrm{~min}$ for each, i.e. the operation lasted only $30 \mathrm{~min}$ more. They preferred the branches of the internal carotid artery (superior thyroid, lingual, facial, ascending pharyngeal) for supercharge and the jugular vein for venous anastomosis [42].

\section{Stimulation of collateral blood flow in colonic graft}

In 1908, Veksner conducted experiments to study the blood supply of a small intestine loop derived from the abdominal cavity. They consecutively ligated the mesenteric vessels [43].

In 1950, Schumacher Jr. and Battersby (Medical Centre at Indiana University Hospital, Indianapolis, USA) carried out an original experiment to assess the collateral blood flow of the small intestine in animals. Forty-six albino rats were operated. Roux-en-Y loop 
was prepared in all animals. The first jejunal artery was preserved. One-stage consecutive ligation of the remaining arteries was performed, or every second artery was ligated in a two-stage procedure. It has been proven that the consecutive ligation of three first-order arteries did not cause ischaemia of the jejunum. The consecutive ligation of four or more arteries resulted in intestinal gangrene. Every second of 3-5 arteries was ligated in 18 animals. From 9 days to 3 months after the first procedure, 3-5 second-order arteries were ligated. Roux-en-Y loop was viable; blood supply was adequate thanks to collateral circulation. Similar results have been obtained in the jejunum and ileum of 16 dogs. This technique ensured the successful derivation of hypervascularised small intestine subcutaneously to the cervical region after transecting all vessels that had been previously ligated [44].

Hadidi supported the idea of Schumacher Jr.-Battersby for oesophagocoloplasty. Between 1999 and 2002 he operated on 11 children with oesophageal post-burn strictures. When performing the gastrostomy, he ligated the middle colic artery and vein. After this, hypervascularisation of the transverse colon was provided from the left colonic artery and the arc of Riolan. Not earlier than 1 month later, he performed the retrosternal colonic interposition for oesophageal replacement [45].

\section{Our experience in hypervascularisation of colonic graft}

For more than 10 years, we have been supporting the preoperative mesentericography at the Endovascular Unit of our Surgery Department. Invasive angiography was performed in 19 of 28 cases (67.9\%). We prefer the "Bordeaux" technique of oesophagoplasty [46]; therefore, we always start with superior mesentericography. When an anomalous branching of the superior mesenteric artery is detected, we perform inferior mesentericography [47]. In the right colonic interposition, angiography was performed in 14 of 16 cases $(87.5 \%)$, in the left - in 5 of 12 cases $(41.7 \%)$. We believe angiography to be mandatory for all patients older than 60 years and in the presence of obliterating atherosclerosis of the lower extremities vessels. It should be noted that in 2 of 14 upper mesentericographies (14.2\%), an anomalous blood supply was identified. In these cases, intraoperative assessment of right colic vessels branching proved to be more encouraging, thus allowing "Bordeaux" oesophagocoloplasty to be successfully completed.

De Meester and Furst used the endoscopic examination of the mucosa to assess the colonic graft blood supply after the procedure [17, 21]. We consider this manipulation not to be safe for cervical oesophagocolonic anastomosis, and developed the technique of transcutaneous Doppler control of the cervical graft blood supply [47].

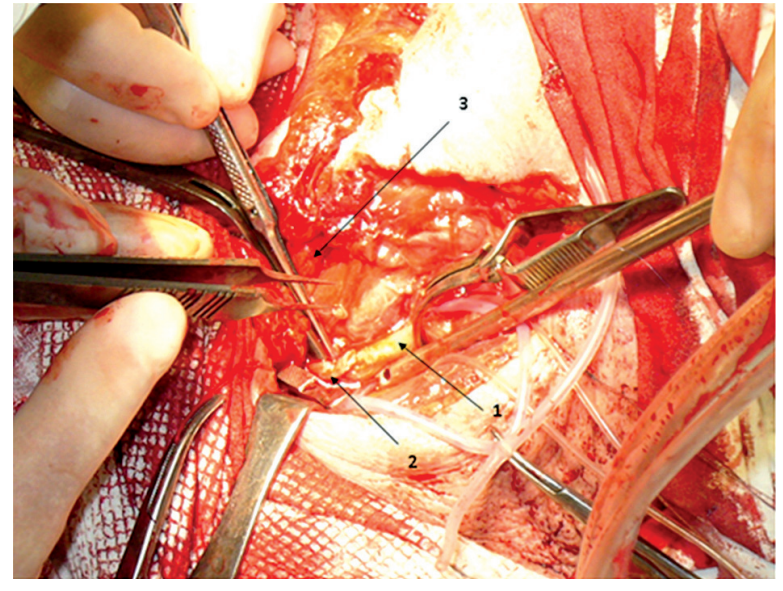

Figure 1. Intraoperative view of the neck wound: vascular pedicle of right colonic graft

1 - left common carotid artery clutched with a "bulldog" clip; 2 - ileocolic artery lengthened by autovein of patient; 3 - ileal part of right colonic graft.

In our practice, there was one case of direct revascularisation [47]. A 69-year-old patient had an anomalous branching of the superior and inferior mesenteric arteries (Figure 1).

Direct revascularisation of the right colonic graft was planned for August 30, 2007. The middle colic artery was chosen as a supply pedicle. The vascular pedicle was prepared from the ileocolic artery; it was suggested that the graft be supplied from the left common carotid artery. However, after routing the ileocolonic graft to the cervical region, the length of the vascular pedicle proved to be insufficient. Therefore, the autovenous insertion was prepared. We performed two vascular anastomoses: the ileocolic artery with venous insertion "end-to-end" and the other end of the venous insertion with the left common carotid artery "end-to-side". The venous anastomosis was not created.

A transient venous hypertension was observed in a viable graft. In the literature, we have not found any case report of the direct revascularisation of the cervical portion of intestinal graft using an autovenous insertion for lengthening a vascular pedicle.

Conversely to Hadidi's idea [45], we proposed revascularisation of the left colonic graft. On September 5, 2008, after poor outcomes of the superior and inferior mesentericography, we performed for the first time laparoscopic clipping of the left colic artery without preliminary laparotomy and gastrostomy in a 58-year-old male patient. An adequate hypervascularisation of the left colonic graft allowed us to perform a successful retrosternal oesophagocoloplasty and create one-stage oesophagosigmoanastomosis on the neck on November 21, 2008. We also grounded the technique of laparoscopic clipping of the right colic vessels for the hypervascularisation [47]. 


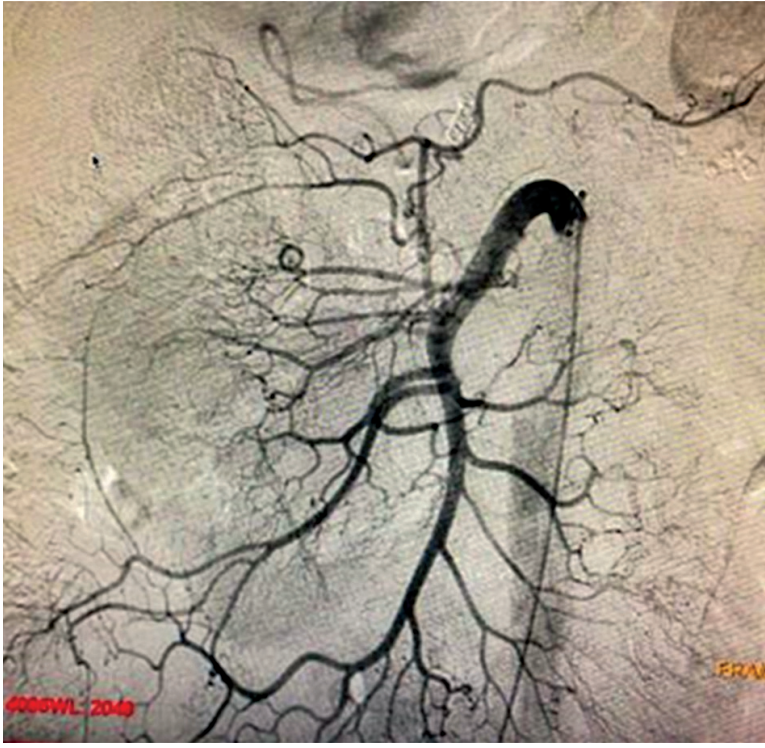

Figure 2. Upper mesentericography: magistral pattern of the right colon blood supply

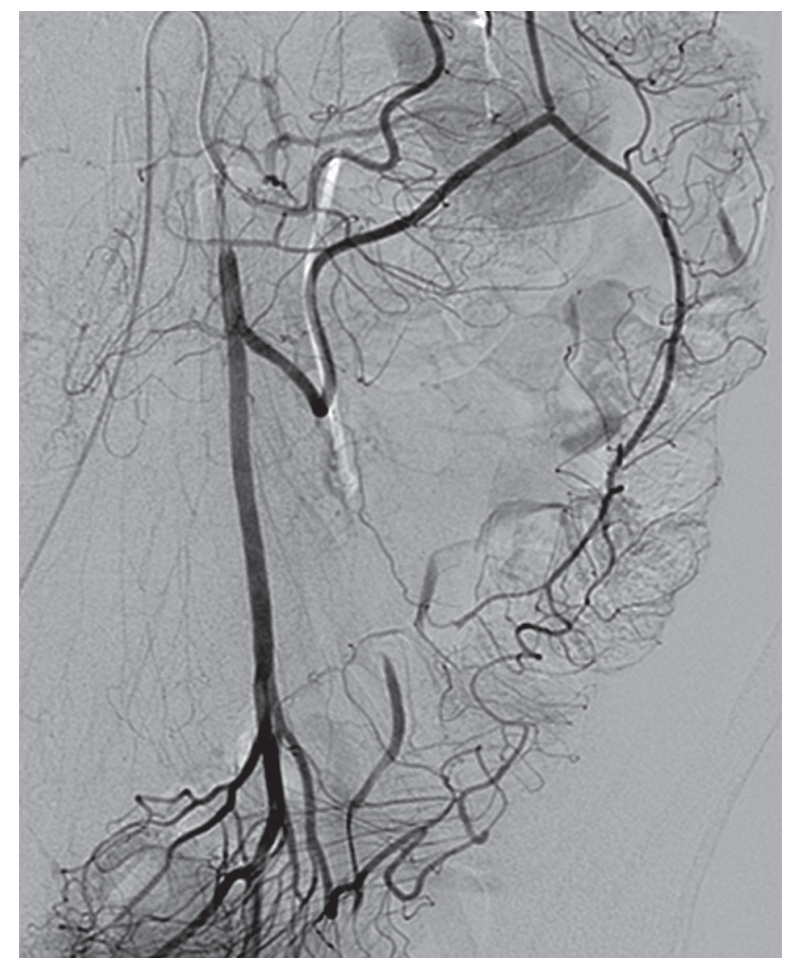

Figure 4. Repeated lower mesentericography performed 13 months after the sigmoid artery ligation: hypervascularisation of the left colon and the rectum

For the second time, we had to ligate the sigmoid artery for the hypervascularisation of the left colon after failed oesophagocoloplasty by the right colon. In this case, surgical rehabilitation of the patient took 2.5 years. We have not found any information about a successful re-oesophagocoloplasty after the method

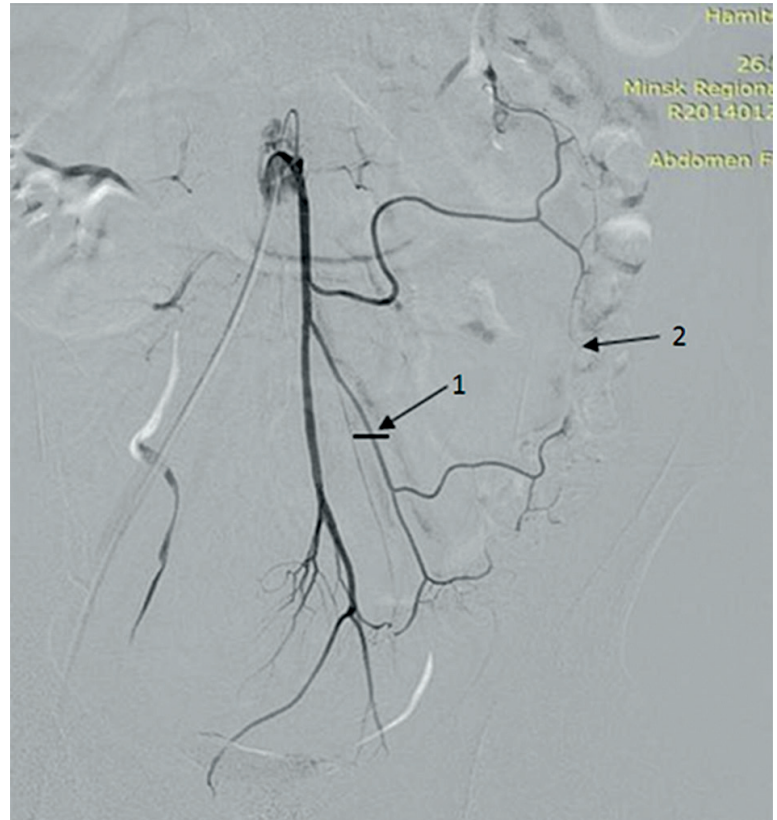

Figure 3. Lower mesentericography: anomalous branching of the inferior mesenteric artery

1 - sigmoid artery ligation; 2 - discontinuous marginal vessel.

of Schumacher Jr., Battersby, and Hadidi in English-language publications. Here is our case report, in brief [48].

The patient $H ., 30$ years old, one month after an alkaline burn of the oesophagus, underwent gastrostomy in our Centre on December 7, 2012. On April 12, 2013, the oesophagocoloplasty was performed using the "Bordeaux" method. The findings from the upper mesentericography confirmed the magistral pattern of blood flow with an appropriate marginal vessel (Figure 2).

On day 6, due to right colonic graft necrosis, the patient had to undergo re-laparotomy, graft resection with cervical oesophagostomy, and nutrition jejunostomy. On May 12, 2013, during the repeated laparotomy, we resected "vicious" jejunostomy, performed visceral lysis and re-gastrostomy.

The patient gained weight and felt better. On January 23, 2014 the lower mesentericography revealed extremely insufficient vascular collaterals of the left colon (Figure 3).

On January 28, 2014 we performed laparotomy, total visceral lysis, and sigmoid artery ligation for hypervascularisation of the left part of the colon after the method of Schumacher-Hadidi. Almost 1 year later, on January 18, 2015, repeated inferior mesentericography revealed a well-developed revascularisation of the left colon (Figure 4).

On February 20, 2015, we performed laparotomy and intrapleural oesophageal replacement with left colonic graft. Using an endoscope, we passed the graft through the right pleural cavity behind the root of the lung to avoid the thoracotomy. We created oesophago- 
sigmoidal anastomosis on the neck using a single-layer suture, then cologastric anastomosis "end-to-side" and ileorectostomy "end-to-side" by Sarli et al. [49]. There were no postoperative complications. The gastrostomy closed spontaneously. Currently, the patient has a body mass index of $22.3 \mathrm{~kg} / \mathrm{m}^{2}$ and no electrolyte disorders.

In this case, the small intestine graft was not considered for the oesophageal replacement for the following reasons: 1) the right colon was already absent; 2) the patient was asthenic, quite a large portion of the jejunum was to be used for the successful subcutaneous oesophagocoloplasty that could lead to short bowel syndrome (in the best case) or to graft necrosis (in the worst); 3) the shorter retrosternal access was used earlier; 4) resection of the oesophagus and pulling the graft through the posterior mediastinum as the shortest route requires not only laparotomy but also thoracotomy.

Thus, 3 of 28 cases $(10.7 \%)$ required the hypervascularisation of the future left colonic graft.

\section{Conclusions}

The analysis of preoperative mesentericography findings, prevention of venous stasis in the colonic graft in retrosternal oesophagoplasty, and mastering the techniques of hypervascularisation of the colonic graft allow significant reducing in the risk of ischaemia in this segment. This contributes to performing one-stage colonic replacement followed by minimal postoperative complications. Good long-term functional results of the shunting oesophagocoloplasty will be achieved.

\section{Conflict of interest}

The authors declare no conflict of interest.

\section{References}

1. Kelling GE. Osophagoplastik mit Hilte das Querkolons. Zentralbl Chir 1911; 38: 1209-12.

2. Thomas P, Fuentes P, Giudicelli R, Reboud E. Colon interposition for esophageal replacement: current indications and long-term function. Ann Thorac Surg 1997; 64: 757-64.

3. Ahmed A, Spitz L. The outcome of colonic replacement of the esophagus in children. Prog Pediatr Surg 1986; 18: 37-54.

4. Freeman NV, Cass DT. Colon interposition: a modification of the Waterston technique using the normal esophageal route. J Pediatr Surg 1982; 17: 17-21.

5. De Meester TR, Johansson KE, Franze I, Eypasch E, Lu CT, Megill JE, Zaninotto G. Indications, surgical technique and long-term functional results of colon interposition or bypass. Ann Surg 1988; 208: 460-74.

6. Sonneland J, Anson BJ, Beaton LE. Surgical anatomy of the arterial supply to the colon from the superior mesenteric artery based upon a study of 600 specimens. Surg Gynec Obstet 1958; 106: 385-98.

7. Seldinger SI. Catheter replacement of the needle in percutaneous arteriography: a new technique. Acta Radiol 1953; 39: 368-76.
8. Marston A. Vascular Disease of the Gut: Pathophysiology, Recognition and Management. E. Arnold, London 1985.

9. Ventemiglia R, Khalil KG, Frazier OH, Mountain CF. The role of preoperative arteriography in colon interposition. Surg 1977; 74: 98-104.

10. Baum S. Normal anatomy and collateral pathways of the mesenteric circulation. In: Vascular Disorders of the Intestine. Boley SI (ed.). Appleton-Century-Crofts, New York, London 1971.

11. Beck AR, Baranofsky ID. A study of the left colon as a replacement for the resected esophagus. Surgery 1960; 48: 499-509.

12. Pouyet M, Berard PH, Bousquet G. Documents anatomiques sur l'emploi du colon transverse isoperistaltique pour oesophagoplastie. Lyon Chir 1967; 63: 199-207.

13. Kralik J, Turek K. Die Wichtigkeit des Venosen Abflusses aus dem zur osophagoplastik verwendeten kolon-transplantat. Zentralbl Chir 1967; 44: 2772-6.

14. Nick R. Colonic replacement of the oesophagus. Some observations on infarction and wound leakage. Br J Surg 1967; 54: 124-8.

15. Thomas P, Fuentes P, Guidichelli R, Redoud E. Colon interposition for esophageal replacement: current indication and long-term function. Ann Thorac Surg 1997; 64: 757-64.

16. Fisher DF, Fry FJ. Collateral mesenteric circulation. Surg Gynec Obstet 1987; 164: 487-92.

17. De Meester TR. Esophageal replacement with colon interposition. Oper Tech Cardiac Thorac Surg 1997; 2: 73-86.

18. Peters JH, Kronson JW, Katz M, De Meester TR. Arterial anatomic considerations in colon interposition for esophageal replacement. Arch Surg 1997; 130: 858-63.

19. De Meester TR, Kauer WK. Esophageal reconstruction. The colon as an esophageal substitute. Dis Esophagus 1995; 8: 20-9.

20. Wain JC, Wright CD, Kuo EY, Moncure AC, Wilkins EW, Grillo HC, Mathisen DJ. Long-segment colon interposition for acquired esophageal disease. Ann Thorac Surg 1999; 67: 313-8.

21. Furst H, Hartl WH, Lohe F, Schilberg FW. Colon interposition for esophageal replacement. Ann Surg 2000; 231: 173-8.

22. Loinaz C, Altorki NK. Pitfalls and complications of colon interposition. Chest Surg Clin North Am 1997; 7: 533-49.

23. Wilkins EW. Long-segment colon substitution for the esophagus. Ann Surg 1980; 192: 720-5.

24. Yasuda T, Shiozaki H. Esophageal reconstruction using a pedicled jejunum with microvascular augmentation. Ann Thorac Cardiovasc Surg 2011; 17: 103-9.

25. Chang JS, Chen HC, Sharma R, Gedebou TM, Feng M. Microvascular reconstruction of the esophagus using supercharged pedicled jejunum flaps: special indication and pitfalls. Plast Reconst Surg 2002; 110: 742-8.

26. Orringer MB. Reversing esophageal discontinuity. Sem Thorac Cardiovasc Surg 2007; 19: 47-55.

27. Lees W. Colonic replacement after pharyngolaryngectomy. Br J Surg 1967; 54: 541-7.

28. Carrel A. The surgery of blood vessels etc. John Hopkins Hosp Bull 1907; 190: 18-28.

29. Longmire WP Jr. A modification of the Roux technique for antethoracic esophageal reconstruction. Surgery 1947; 22: 94-100.

30. Longmire WP Jr. Congenital atresia and tracheoesophageal fistula four consecutive cases of successful primary esophageal anastomosis. Arch Surg 1947; 55: 330-8. 
31. Androsov PI. Blood supply of mobilized intestineused for an artificial esophagus. AMA Arch Surg 1956; 73: 917-26.

32. Seidenberg B, Rosenak SS, Herwitt ES. Immediate reconstruction of the cervical esophagus by a revascularized isolated jejunal segment. Ann Surg 1959; 149: 162.

33. Schwabegger HH, Ninkovi MM, Morigyl B, Waldenberger P, Brenner E. Internal mammary veins: classification and surgical use in free-tissue transfer. J Reconstr Microsurg 1997; 13: 17-23.

34. Wormuth J, Heitmiller RF. Esophageal conduit necrosis. Thorac Surg Clin 2006; 16: 11-2.

35. Ascioti AJ, Hotstetter WL, Miller MJ, Rice DC, Swischer SW. Long-segment, supercharged, pedicled jejunal flap for total esophageal reconstruction. J Thorac Cardiovasc Surg 2005; 130: 1391-8.

36. Swisher SW, Hofstetter WL, Miller MJ. The Supercharged microvascular jejunal interposition. Semin Thorac Cardiovasc Surg 2007; 19: 56-65.

37. Heitmiller RF, Gruber PJ, Swier P, Singh N. Long-segment substernal flap with internal mammary vascular augmentation. Dis Esophagus 2000; 13: 240-2.

38. Chana JS, Chen HC, Sharma R, Gedebou TM, Feng M. Microvascular reconstruction of the esophagus using supercharged pedicled jejunum flaps: special indication and pitfalls. Plast Reconst Surg 2002; 110: 742-8.

39. Fujita H, Amana H, Sueyoshi S. Impact on outcome of additional microvascular anastomosis supercharge on colon interposition for esophageal replacement: comparative and multivariate analysis. World J Surg 1997; 21: 998-1003.

40. Golshani SD, Lee C, Cass D. Microvascular "supercharged" cervical colon: minimizing ischemia in esophageal reconstruction. Ann Plast Surg 1999; 43: 533-8.

41. O’Rourke JC, Threlfall GN. Colonic interposition for esophageal reconstruction with special reference to microvascular reinforcement of graft circulation. Aust J Surg 1986; 56: 767-71.

42. Shirakawa Y, Naomoto Y, Noma K, Sakirama K, Nishikawa T. Colonic interposition and supercharge for esophageal reconstruction. Langenbecks Arch Surg 2006; 391: 19-23.

43. Veksner BG. Presternal esophagus. Nov Khir Arkhiv 1931; 248-51 (In Russian).

44. Shumacker HB, Battersby JS. The problem of esophageal replacement by jejunum with particular reference to influence upon circulation of staging the division of mesenteric vessels. Ann Surg 1951; 43: 463-71.

45. Hadidi AT. A technique to improve vascularity in colon replacement of the esophagus. Eur J Pediatr Surg 2006; 16: 39-44.

46. Lafargue P, Dufour R, Cabanie H, Chavannaz N. Esophagoplastie prethoracique a L'aide du colon droit et de L'ileon terminal Med. Acad Chir 1951; 77: 362-9.

47. Varabei AV, Chepik DA, Vizhinis EI. One-step retrosternal esophagoplasty in the treatment of patients with postburn cicatrical stricture of the esophagus. Khirurgiya 2014; 7: 26-33 (In Russian).

48. Varabei AV, Vizhinis EI, Popel G, Chepik DA, Maskalik ZG, Makhmudov AM. Post-burn cicatrical stricture of the esophagus: reesophagoplasty. Novosti Khirurgii 2016; 3: 8-22 (In Russian).

49. Sarli L, Iusco D, Violi V, Roncoroni L. Subtotal colectomy with antiperistaltic cecorectal anastomosis. Tech Coloproctol 2002; 6: 23-6.

\section{Address for correspondence:}

\section{Prof. Aliaksandr Varabei}

Belarusian Medical Academy of Postgraduate Education Lesnoe 1, 223041 Minsk, Belarus

Phone: +37 5296554717

E-mail: dept-surg@hotmail.com 